\title{
Kemampuan Siswa dalam Menyelesaikan Masalah Open-Ended Berdasarkan Aspek Fluency, Flexibility, dan Novelty
}

\author{
Rina Ramandani ${ }^{1}$, Hery Susanto ${ }^{1}$, Dwiyana ${ }^{1}$ \\ ${ }^{1}$ Pendidikan Matematika-Universitas Negeri Malang
}

\begin{tabular}{l}
\hline INFO ARTIKEL \\
\hline Riwayat Artikel: \\
Diterima: $12-03-2019$ \\
Disetujui: $14-08-2019$ \\
\hline
\end{tabular}

\section{Kata kunci:}

kemampuan siswa; masalah open-ended; fluency; flexibility; novelty

\section{ABSTRAK}

Abstract: This qqualitative research aims to describe students' ability to solve openended problems based on fluency, flexibility, and novelty aspects. The study was conducted at MTsN 1 Malang. The subjects in this study were four students. The instruments used were interview guidelines and open-ended problem test. The results of this research confirm that highly ability students are able to think broadly and apply many ideas so that they are flexible in making a flat build. He fulfils the fluency, flexibility and novelty aspects. Moderate students are less able to bring up and apply many ideas in answering open-ended problems so that they meet the fluency and flexibility or fluency aspects only. Low-ability students are unable to bring up and apply many ideas to produce many answers so that they do not fulfil all three aspects.

\begin{abstract}
Abstrak: Penelitian kualitatif yang bertujuan untuk mendeskripsikan kemampuan siswa dalam menyelesaikan masalah open-ended berdasarkan aspek fluency, flexibility, dan novelty. Penelitian dilaksanakan di MTsN 1 Malang. Subjek dalam penelitian ini sebanyak empat siswa. Instrumen yang digunakan pedoman wawancara dan lembar tes masalah open-ended. Hasil penelitiannya siswa berkemampuan tinggi mampu berpikir secara luas dan menerapkan banyak ide sehingga fleksibel dalam membuat bangun datar. Ia memenuhi aspek fluency, flexibility, dan novelty. Siswa berkemampuan sedang kurang dapat memunculkan dan menerapkan banyak ide dalam menjawab masalah open-ended sehingga memenuhi aspek fluency dan flexibility atau fluency saja. Siswa berkemampuan rendah tidak mampu memunculkan dan menerapkan banyak ide untuk menghasilkan banyak jawaban sehingga tidak memenuhi ketiga aspek.
\end{abstract}

\author{
Alamat Korespondensi: \\ Rina Ramandani \\ Pendidikan Matematika \\ Universitas Negeri Malang \\ Jalan Semarang 5 Malang \\ E-mail: rinaramandani@gmail.com
}

Open-Approach sudah diterapkan dalam pembelajaran sejak sebelum perang dunia ke-2 di Jepang. Akan tetapi, penelitian tentang pendekatan ini mulai dilakukan pada tahun 1970-an oleh Shimada dan kawan-kawannya (Nohda, 2000). Beberapa tahun kemudian banyak peneliti bergabung dalam penelitian tersebut. Hasil kolaborasi antar peneliti-peneliti tersebut ditulis dalam buku yang berjudul The Open-Ended Approach: A new Proposal for Teaching Mathematics yang sudah diterjemahkan dalam bahasa Inggris kemudian diterbitkan oleh NCTM (Becker, 1997). Kunci utama dalam pendekatan ini adalah pengajuan masalah oleh guru yang disusun sedemikian hingga memiliki banyak jawaban benar dan banyak strategi penyelesaian. Masalah yang demikian disebut sebagai masalah "incomplete" atau masalah "open-ended" sehingga masalah open-ended dapat didefinisikan sebagai masalah yang memiliki banyak jawaban benar dan banyak strategi penyelesaian (Becker \& Shimada, 1997; Joseph, 2009; Nohda, 2000). Definisi tersebut sesuai dengan pendapat (Becker \& Shimada, 1997) yaitu siswa dikatakan sedang menyelesaikan masalah open-ended ketika siswa diminta untuk (1) menemukan banyak jawaban benar, (2) menemukan banyak strategi benar, atau (3) merumuskan masalahnya sendiri. Jenis masalah open-ended antara lain (1) pengambilan keputusan (overcoming fixation); (2) banyak jawaban benar yang berbeda (multiple answer); (3) banyak strategi berbeda (multiple strategies); (4) menginvestigasi strategi (strategy investigation); (5) problem posing; (6) tugas inkuiri aktif (active inqury task); (7) berpikir logika (logical thinking) (Kwon, Park, \& Park, 2006).

Penerapan Open-Approach dalam pembelajaran memberikan keuntungan bagi siswa. Dengan menerapkan OpenApproach dalam pembelajaran dapat mengembangkan kreativitas matematika siswa (Becker, 1997; Fatah, Suryadi, \& Sabandar, 2016; Kwon, Park, \& Park, 2006; Silver, 1994; Nohda, 2000; Okabe, 2000). Dalam hal ini siswa diuntungakan karena mereka perlu membuat keputusan dan merencanakan strategi, seperti mengaplikasikan pengetahuan matematika mereka untuk menyelesaikan masalah open-ended. Penggunaan masalah open-ended memungkinkan lebih banyak diskusi diantara siswa-siswa 
dan membantu mereka menyadari bahwa masalah matematika tidak terbatas untuk selalu memiliki satu jawaban benar. Dengan menggunakan masalah open-ended sebagai katalisator pada diskusi kelas atau diskusi kelompok kecil, siswa tidak hanya dapat mendiskusikan solusi mereka, tetapi juga bagaimana mereka memperoleh solusi mereka tersebut (Joseph, 2009). Secara tidak langsung mereka sedang mengembangkan kemampuannya dalam menyelesaikan masalah (problem solving). Hal tersebut sejalan dengan pendapat (Okabe, Hirotani, \& Sakata, 2000) bahwa masalah open-ended memungkinkan siswa untuk mencoba beragam strategi untuk menyelesaikan masalah serta pendekatan yang berbeda seperti mempelajari strategi baru untuk menerapkan konsep matematika. Selama proses menemukan beragam strategi dan pendekatan siswa mengombinasikan pengetahuan, kemampuan, dan strategi berpikir yang telah mereka pelajari dalam pembelajaran sebelumnya. Masalah open-ended membebaskan siswa untuk menggunakan strategi yang dipilih sehingga memungkinkan untuk dapat membuat koneksi yang lebih besar antar konteks, dan memungkinkan lebih banyak ide yang dapat dibagikan dalam diskusi kelas. Melalui diskusi ini semua siswa dari yang berkemampuan rendah sampai tinggi mempelajari ide-ide baru. Saat itu terjadi, tanpa disadari mereka sedang mengembangkan kreativitas matematika.

Menyikapi tuntunan zaman yang semakin kompetitif, kreativitas yang merupakan salah satu komponen pembelajaran abad 21, diharapkan dapat diimplementasikan dalam pembelajaran seperti yang telah diamanatkan di dalam kurikulum 2013. Salah satu karakteristik dari kreativitas adalah berpikir berbeda (divergent thinking) (Goldberg \& McDermott, 1986). Divergent thinking dapat diartikan berpikir secara luas yang menghasilkan beragam solusi atau jawaban (Iwata, 2000). Runco dan Guilford (Sak, 2005) menyebutkan bahwa berpikir berbeda didefinisikan sebagai kemunculan dan penerapan dari banyak ide untuk menyelesaikan masalah yang diberikan. Fokus dari divergent thinking adalah pada kualitas dan kuantitas dari ide atau respon yang dihasilkan oleh penyelesai masalah dalam proses menyelesaikan masalah. Kreativitas siswa dapat diukur berdasarkan "produk-produk berbeda" yang dihasilkan siswa selama menyelesaikan masalah.

Torrance Test of Creative Thinking (TTCT) sering digunakan untuk mengukur kreativitas anak-anak dan orang dewasa. Tiga komponen kreatifitas yang diukur melalui TTCT antara lain kebaruan (novlety /originality), fleksibilitas (flexibility), dan kefasihan (fluency) (Silver, 1994). Siswa dikatakan memenuhi komponen novelty/originality jika siswa mampu memberikan solusi atau strategi yang baru (tidak biasa dibuat siswa pada tingkat berpikir pada umumnya). Siswa dikatakan memenuhi indikator flexibility jika siswa mampu menyelesaikan masalah dengan banyak strategi yang berbeda. Siswa dapat dikatakan memenuhi indikator fluency jika siswa mampu menyelesaikan masalah dengan membuat banyak jawaban benar yang berbeda. Selain TTCT instrumen lain yang dapat digunakan untuk mengukur berpikir kreativitas siswa adalah masalah open-ended (Becker, 1997; Silver \& Cai, 1997; Imai, 2000; Nohda, 2000; Siswono, 2010).

(Imai, 2000) menggunakan masalah open-ended jenis pengambilan keputusan (overcoming fixation) untuk mengetahui hubungan antara fluency dan flexibility dalam berpikir berbeda (divergent thinking) dan pengambilan keputusan dalam matematika. Hasil dari penelitiannya, siswa yang dapat mengambil keputusan dalam matematika cenderung mudah dalam membuat beragam ide untuk menyelesaikan masalah (flexibility). Sedangkan siswa yang tidak dapat mengatasi fiksasi matematika dapat menyelesaikan masalah yang mirip dalam waktu singkat (fluency). Penelitian lain yang menggunakan masalah open-ended sebagai instrumen penelitian adalah (Siswono, 2010).

(Siswono, 2010) menggunakan masalah open-ended untuk melevelkan berpikir kreatif. Dalam artikelnya (Siswono, 2010) menjelaskan ada lima tingkatan berpikir kreatif, yaitu level 4 (memenuhi tiga indikator (fluency, flexibility, novelty) atau dua indikator (novelty and flexibility)), level 3 (memenuhi indikator flexibility dan fluency atau novelty and fluency), level 2 (memenuhi indikator novelty or flexibility tetapi tidak keduanya), level 1 (memenuhi indikator fluency saja), dan level 0 (tidak memenuhi ketiga indikator berpikir kreatif). Instrumen dalam penelitiannya berupa masalah open-ended jenis multiple answer, multiple strategies, dan problem posing pada bagun datar. Subjek diminta untuk menggambar bangun datar yang luasnya sama dengan luas bangun datar yang diketahui pada soal dan mengajukan permasalahan terkait bangun datar tersebut.

Kesamaan dari penelitian yang dilakukan oleh (Imai, 2000; Siswono, 2010) adalah keduanya tidak mengeksplorasi bagaimana subjeknya dapat atau tidak dapat menemukan banyak jawaban benar, banyak strategi berbeda, dan ide-ide baru untuk menyelesaikan masalah open-ended. Padahal dengan mengeksplorasi hal tersebut peneliti dapat mengetahui factor yang mempengaruhi kemampuan siswa dalam mengerjakan masalah open-ended. Seperti kata pepatah "jika diketahui sakitnya maka bisa dicari obatnya", jika kita sebagai pendidik mengetahui faktor-faktor yang memengaruhi kemampuan siswa dalam mengerjakan masalah open-ended harapannya kita mampu membuat renacana pembelajaran yang dapat meningkatkan kemampuan mereka dalam menyelesaikan masalah open-ended. Selain itu, mengingat bahwa masalah open-ended merupakan instrumen yang dapat digunakan untuk mengukur tingkat kreativitas siswa. Oleh karena itu, penelitian ini dilaksanakan untuk mendeskripsikan kemampuan siswa dalam menyelesaikan masalah open-ended berdasarkan aspek fluency, flexibility, dan novelty.

\section{METODE}

Penelitian ini merupakan penelitian kualitatif yang bertujuan untuk mendeskripsikan profil siswa dalam menyelesaikan masalah open-ended berdasarkan aspek fluency, flexibility, dan novelty. Penelitian ini dilaksanakan di MTsN 1 Malang. Subjek dalam penelitian ini adalah satu siswa berkemampuan tinggi, dua siswa berkemampuan sedang, dan satu siswa berkemampuan 
rendah. Pemilihan subjek dilakukan berdasarkan pencapaian akademis siswa pada mata pelajaran matematika selama pembelajaran dan rekomendasi guru terkait siswa yang memiliki kemampuan komunikasi yang lancar. Teknik pengumpulan data yang digunakan dalam penelitian ini adalah tes tertulis dan wawancara. Instrumen dalam penelitian ini berupa soal open-ended tentang konsep luas dan bangun datar dan pedoman wawancara tidak terstruktur yang bertujuan untuk mengeksplorasi kemampuan siswa dalam menyelesaikan masalah open-ended berdasarkan hasil pekerjaan tertulis subjek. Dari hasil tes tertulis dan wawancara tersebut selanjutnya dideskripsikan kemampuan siswa dalam menyelesaikan masalah open-ended berdasarkan aspek fluency, flexibility, dan novelty. Instrumen yang digunakan berupa pedoman wawancara dan lembar tes masalah open-ended seperti berikut ini.

Diberikan persegi panjang dengan ukuran $2 \mathrm{~cm}$ x $3 \mathrm{~cm}$ seperti pada gambar 1 . Buatlah bentuk arsiran berbeda sebanyak banyaknya yang luasnya $1 \mathrm{~cm}^{2}$ pada persegi panjang tersebut! (catatan: buatlah persegi panjang seperti gambar di atas sebanyak arsiran yang dapat kamu buat).

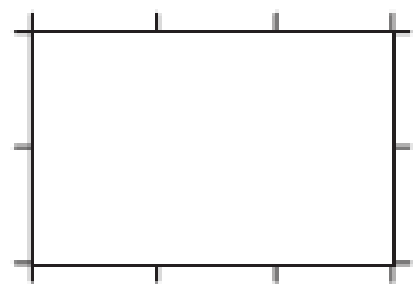

Gambar 1. Buatlah bentuk arsiran berbeda sebanyak banyaknya yang luasnya $1 \mathrm{~cm}^{2}$ pada persegi panjang

HASIL

Subjek Berkemampuan Tinggi (S1)

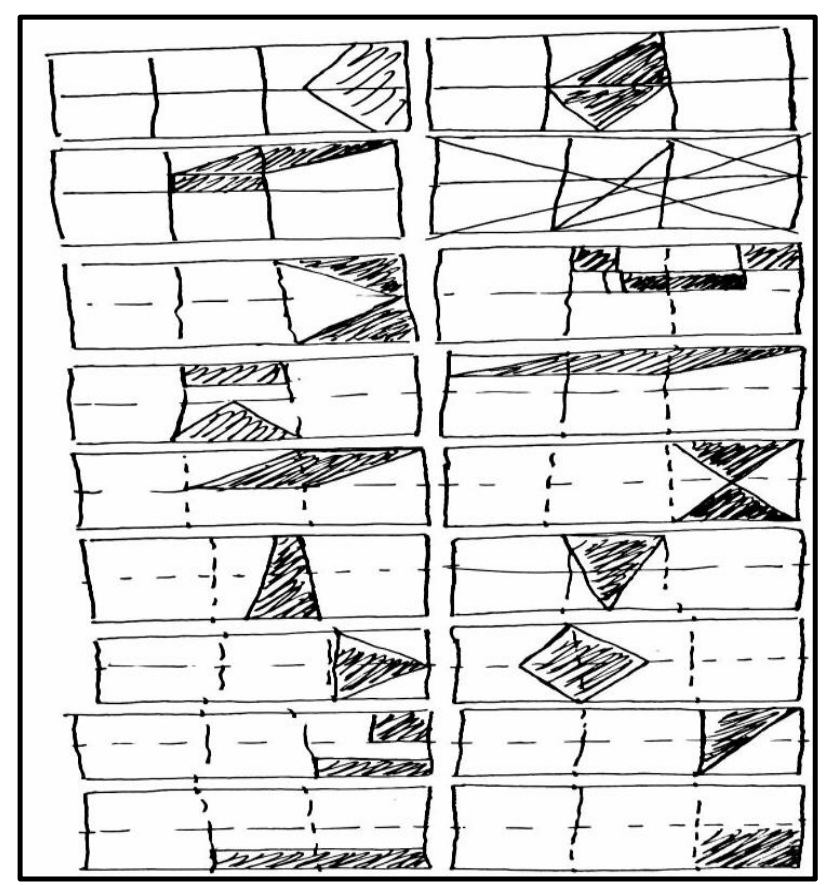

Gambar 2. Hasil Pekerjaan Tertulis S1

Pada gambar 2 merupakan hasil pekerjaan S1 dalam mengerjakan soal tes kemampuan berpikir kreatif. Dari gambar 2 dapat dilihat bahwa S1 dapat membuat banyak bentuk arsiran berbeda antara lain segitiga siku-siku dengan panjang alas $2 \mathrm{~cm}$ dan tinggi $1 \mathrm{~cm}$, segitiga sama kaki dengan panjang alas $2 \mathrm{~cm}$ dan tinggi $1 \mathrm{~cm}$, segitiga sama kaki dengan panjang alas $1 \mathrm{~cm}$ dan tinggi $2 \mathrm{~cm}$, jajargenjang dengan panjang alas $1 \mathrm{~cm}$ dan tinggi $1 \mathrm{~cm}$, jajargenjang dengan panjang alas $2 \mathrm{~cm}$ dan tinggi $0,5 \mathrm{~cm}$, persegi panjang dengan panjang $2 \mathrm{~cm}$ dan tinggi $0,5 \mathrm{~cm}$, trapesium siku-siku dengan panjang sisi sejajarnya $\frac{1}{3} \mathrm{~cm}$ dan $\frac{2}{3} \mathrm{~cm}$ dan 
tingginya $2 \mathrm{~cm}$, dua buah segitiga sama kaki yang masing-masing luasnya $0,5 \mathrm{~cm}^{2}$, dua buah persegi panjang yang masing-masing luasnya $0,5 \mathrm{~cm}^{2}$, persegi panjang dan segitiga sama kaki yang masing-masing luasnya $0,5 \mathrm{~cm}^{2}$, dua buah trapesium siku-siku yang masing-masing luasnya $0,5 \mathrm{~cm}^{2}$, belah ketupat dengan panjang diagonal $1 \mathrm{~cm}$ dan $2 \mathrm{~cm}$, gabungan bangun segitiga sama kaki dan siku-siku yang masing-masing luasnya $0,5 \mathrm{~cm}^{2}$, dua buah persegi panjang yang masing-masing luasnya $0,5 \mathrm{~cm}^{2}$, dan gabungan bangun datar sedemikian hingga luasnya $1 \mathrm{~cm}^{2}$. S1 dapat membuat banyak bentuk arsiran yang berbeda maka ia dapat dikatakan memenuhi indikator berpikir kreatif fluency.

Dari gambar 2 juga dapat diamati strategi yang digunakan oleh S1 dalam membuat bangun dan ukuran yang berbeda yaitu dengan membagi persegi panjang menjadi enam persegi yang kongruen dengan luas $1 \mathrm{~cm}^{2}$. Dengan cara demikian mempermudah S1 untuk memperkirakan ukuran dan letak dimana ia harus membuat arsiran sehingga luas arsiran yang ia buat tepat $1 \mathrm{~cm}^{2}$. Selanjutnya berikut adalah potongan transkrip wawancara peneliti dengan $\mathrm{S} 2$.
P : "bagaimana kamu membuat bentuk arsiran yang ini" (sambil menunjuk bentuk arsiran yang dimaksud)
S1 : "oh kalau yang ini saya modifikasi, saya membuat dua buah persegi panjang yang masing-masing luasnya $0,5 \mathrm{~cm}^{20}$
$\mathrm{P} \quad$ : "apa bedanya segitiga-segitiga yang kamu buat?" (sambil menunjuk beberapa bentuk arsiran segitiga)
S1 : "ini kan jenis segitiganya berbeda, yang ini segitiga siku-siku, ini segitiga sama kaki, yang ini panjang alasnya $1 \mathrm{~cm}$ tingginya $2 \mathrm{~cm}$, kalau yang ini panjang alasnya $2 \mathrm{~cm}$ tingginya $1 \mathrm{~cm} "$
P $\quad$ : "kalu bentuk arsiran yang ini?" (sambil menunjuk bentuk arsiran yang dimaksud)
S2 : "ini saya modifikasi, yang ini dua buah segitiga sama kaki yang masing-masing luasnya $0,5 \mathrm{~cm}^{2}$, yang ini kombinasi antara segitiga dan persegi panjang yang masing-masing luasnya $0,5 \mathrm{~cm}^{2}$, yang ini gabungan segitiga sama kaki dan segitiga siku- siku, yang ini gabungan dua buah trapesium siku-siku yang masing-masing luasnya $0,5 \mathrm{~cm}^{2 \prime \prime}$

Berdasarkan hasil pekerjaan tertulis dan potongan transkrip wawancara, S1 dengan fleksibel dapat membuat bangun dan ukuran yang berbeda-beda. S1 juga dapat membuat arsiran dengan menggabungkan beberapa bangun datar sedemikian hingga luasnya $1 \mathrm{~cm}^{2}$. Jawaban berupa gabungan beberapa bangun datar tidak dapat oleh subjek yang kemampuan matematisnya dibawah S1. Oleh karena itu, S2 dapat dikatakan memenuhi aspek flexibility dan novelty.

\section{Subjek Berkemampuan Sedang (S2)}

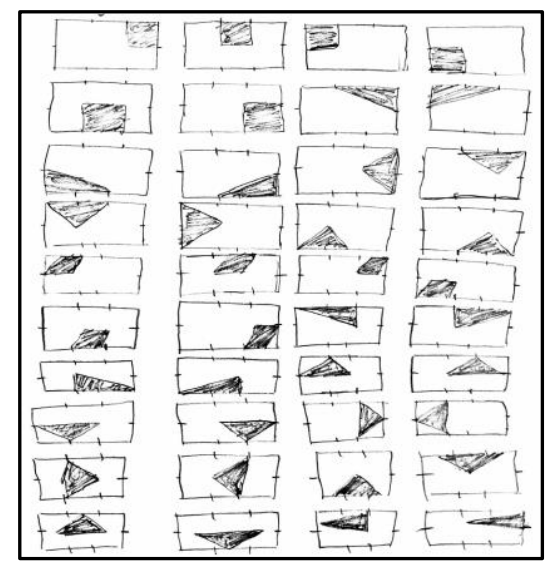

\section{Gambar 3. Hasil Pekerjaan Tertulis S2 dalam menjawab LTBK}

Gambar 3 merupakan hasil pekerjaan S2 dalam mengerjakan soal tes kemampuan berpikir kreatif. Pada gambar 3 menunjukkan S2 dapat membuat beberapa bentuk arsiran antara lain persegi yang panjang sisinya $1 \mathrm{~cm}$, segitiga siku-siku yang tingginya $1 \mathrm{~cm}$ dan panjang alasnya $2 \mathrm{~cm}$, segitiga sama kaki yang panjang alasnya $2 \mathrm{~cm}$ dan tingginya $1 \mathrm{~cm}$, segitiga sama kaki yang panjang alasnya $1 \mathrm{~cm}$ dan tingginya $2 \mathrm{~cm}$, dan jajargenjang yang panjang alasnya $1 \mathrm{~cm}$ dan tingginya $1 \mathrm{~cm}$. S2 dapat membuat lebih dari satu bentuk arsiran berbeda. Oleh karena itu, S2 memenuhi indikator fluency.

S2 mampu membuat arsiran berbentuk segitiga siku-siku dan segitiga sama kaki dengan ukuran yang berbeda-berbeda. Ia fleksibel dalam menentukan ukuran segitiga sehingga mampu mendapatkan banyak jawaban yang berbeda. Kelemahan dari S2 adalah ia tidak atau belum mengeksplorasi bentuk-bentuk bangun datar yang lain sehingga ia hanya mampu membuat persegi, segitiga, dan jajargenjang walaupun setelah dicermati lagi ternyata ukuran dan gambar jajargenjang yang ia buat tidak sesuai. Apabila hasil pekerjaan tertulis S2 diamati, strategi yang ia digunakan untuk membuat bangun datar adalah dengan menggunakan bantuan grid pada frame. Hasil wawancara di bawah ini menjelaskan bagaimana ia dapat membuat bentuk arsiran segitiga dengan cara yang berbeda. 
P : "bagaimana kamu membuat bentuk arsiran segitiga-setiga ini" (sambil menunjuk segitiga siku-siku dan segitiga sama kaki) : "saya buat segitiga nya beda, yang ini segitiga siku-siku, yang ini segitiga sama kaki-kaki, bedanya di yang ini alasnya 2 cm tingginya $1 \mathrm{~cm}$, yang ini alasnya $1 \mathrm{~cm}$ tingginya $2 \mathrm{~cm} "$

$\mathrm{P} \quad$ : : "kalau yang ini?" (sambil menunjuk segitiga yang ditengah frame)

S4 : "kalo yang ini puncaknya ditengah-tengah, kalo segini kan $1 \mathrm{~cm}$ (sambil menunjukkan grid), berarti kanan kiri tinggal ditambah setengah biar alasnya jadi $2 \mathrm{~cm} "$

Siswa dikatakan memenuhi aspek novelty dalam penelitian ini apabila ia dapat membuat bentuk arsiran dari gabungan beberapa bangun seperti yang dibuat oleh S1. Dikarenakan S2 belum mampu membuat bentuk arsiran yang seperti itu, maka ia dikatakan belum novelty.

\section{Subjek Berkemampuan Sedang (S3)}

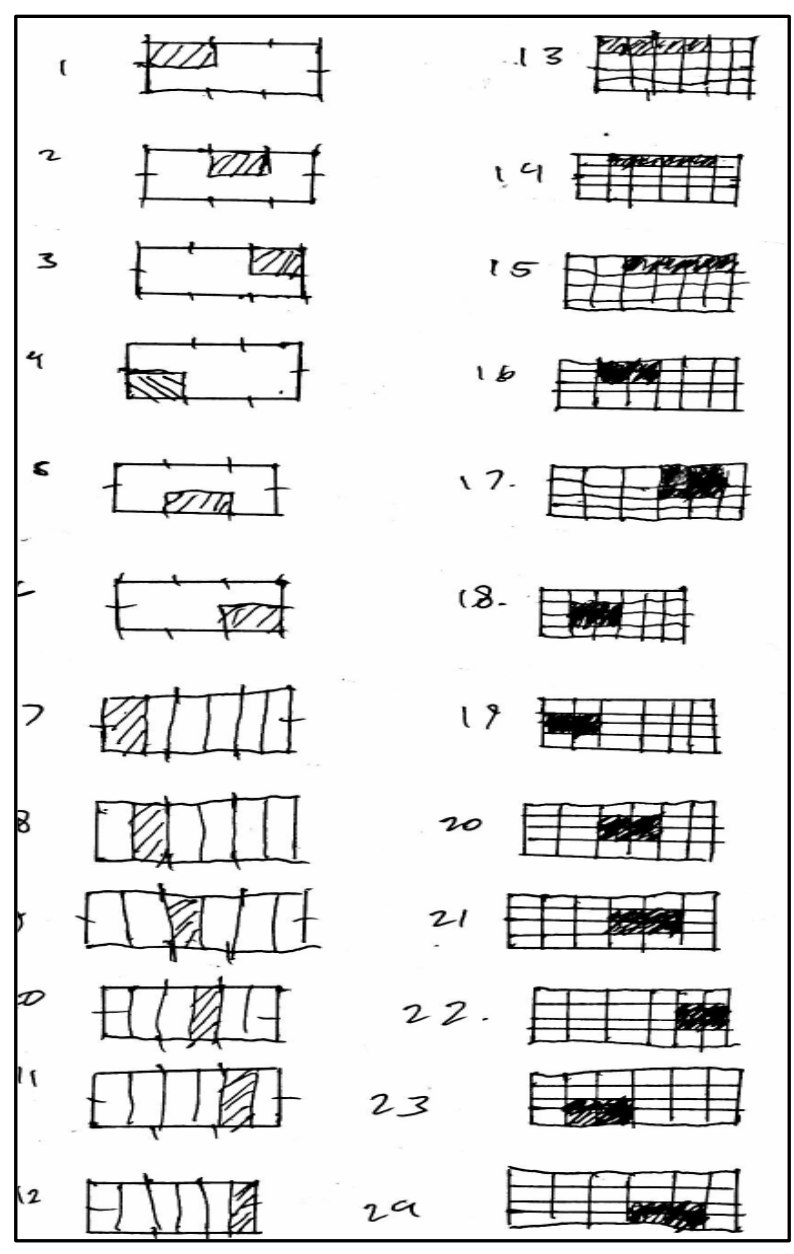

Gambar 4. Hasil Pekerjaan Tertulis S3

Gambar 4 merupakan hasil pekerjaan S3 dalam mengerjakan soal tes kemampuan berpikir kreatif. Dari gambar 4 dapat dilihat bahwa S3 membuat bangun datar persegi panjang dengan berbagi macam ukuran, yaitu persegi dengan panjang sisi $1 \mathrm{~cm}$ dan persegi panjang dengan panjang $2 \mathrm{~cm}$ dan lebar $0,5 \mathrm{~cm}$. S3 membuat banyak persegi yang sama ukurannya dan persegi panjang yang sama ukurannya dan letaknya berbeda-beda. Dalam penelitian ini siswa dikatakan memenuhi aspek fluency apabila siswa mampu membuat bangun datar yang luasnya $1 \mathrm{~cm}^{2}$ dengan ukuran yang berbeda-beda. Siswa dikatakan memenuhi aspek flexibility apabila siswa mampu membuat minimal dua bangun datar yang berbeda, tetapi S3 hanya mampu membuat bangun datar persegi panjang maka S3 dikatakan belum memenuhi aspek flexibility. Siswa dikatakan memenuhi aspek novelty apabila siswa dapat membuat bangun datar dari gabungan beberapa bangun datar, tetapi S3 hanya mampu membuat bangun datar persegi panjang maka S3 dikatakan belum memenuhi aspek novelty. 
Subjek Berkemampuan Rendah (S4)

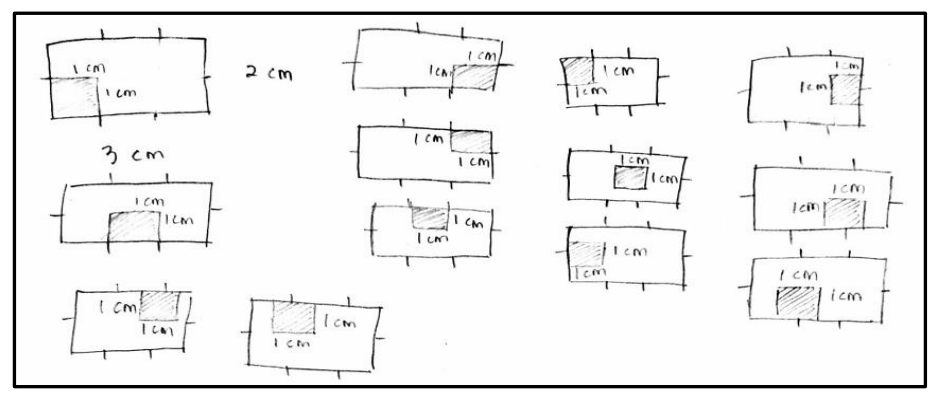

Gambar 5. Hasil Pekerjaan Tertulis S4

Pada gambar 5 merupakan hasil pekerjaan S4 dalam mengerjakan soal tes kemampuan berpikir kreatif. Berdasarkan gambar 5, S4 membuat banyak bangun persegi dengan ukuran sisi $1 \mathrm{~cm}$ yang berbeda posisinya. Dalam penelitian ini siswa dikatakan memenuhi aspek fluency apabila siswa mampu membuat bangun datar yang luasnya $1 \mathrm{~cm}^{2}$ dengan ukuran yang berbedabeda, oleh karena S4 hanya mampu membuat satu bangun persegi dengan ukuran sisi $1 \mathrm{~cm}$ maka S4 dikatakan belum memenuhi aspek fluency. Siswa dikatakan memenuhi aspek flexibility apabila siswa mampu membuat minimal dua bangun datar yang berbeda, oleh karena S4 hanya mampu membuat satu bangun persegi dengan ukuran sisi $1 \mathrm{~cm}$ maka S4 dikatakan belum memenuhi aspek flexibility. Siswa dikatakan memenuhi aspek novelty apabila siswa dapat membuat bangun datar dari gabungan beberapa bangun datar, oleh karena S4 hanya mampu membuat satu bangun persegi dengan ukuran sisi $1 \mathrm{~cm}$ maka S4 dikatakan belum memenuhi aspek novelty. Berikut adalah potongan transkrip wawancara yang menunjukkan S4 tidak memenuhi ketiga aspek.

\footnotetext{
P $\quad$ : "bentuk arsiran apa saja yang kamu buat? coba jelaskan "

S7 : : "persegi, ini panjang sisinya $1 \mathrm{~cm}$, jadi luasnya $1 \mathrm{~cm}^{2 "}$ "

$\mathrm{P} \quad$ : "bagaimana kamu membuat persegi yang lain?".

S7 : : "kan nggak cuman di sini, jadi dipindah-pindah perseginya".
}

Berdasarkan ulasan di atas, siswa yang berkemampuan matematis tinggi memenuhi ketiga aspek, yaitu fluency, flexibility, dan novelty. Siswa yang berkemampuan matematis sedang memenuhi aspek fluency dan flexibility. Siswa yang berkemampuan matematis rendah tidak memenuhi ketiga aspek. Hasil tersebut tersaji pada tabel 1.

Tabel 1. Profil Siswa Berdasarkan Aspek Fluency, Flexibility, dan Novelty

\begin{tabular}{cccc}
\hline Subjek & Fluency & Flexibility & Novelty \\
\hline S1 & $\sqrt{ }$ & $\sqrt{ }$ & $\sqrt{ }$ \\
\hline S2 & $\sqrt{ }$ & $\sqrt{ }$ & $\times$ \\
\hline S3 & $\sqrt{ }$ & $\times$ & $\times$ \\
\hline S4 & $\times$ & $\times$ & $\times$ \\
\hline
\end{tabular}

\section{PEMBAHASAN}

Berdasarkan hasil, subjek yang berkemampuan tinggi dan sedang dapat membuat banyak jawaban benar yang berbeda. Hal tersebut menunjukkan bahwa subjek berkemampuan tinggi dan sedang memenuhi aspek fluency (Kwon, Park, \& Park, 2006; Silver, 1994; Siswono, 2010). Subjek yang berkemampuan tinggi fleksibel dalam membuat bentuk arsiran yang berbeda. Hal tersebut menunjukkan bahwa subjek berkemampuan tinggi memenuhi aspek flexibility (Kwon, Park, \& Park, 2006; Silver, 1994; Siswono, 2010). Berdasarkan hasil, subjek yang berkemampuan sedang memenuhi aspek fluency atau flexibility. Subjek yang berkemampuan tinggi mampu membuat bentuk arsiran dari gabungan dua buah bangun yang tidak dapat dibuat oleh subjek yang lain. Hal tersebut menunjukkan bahwa subjek berkemampuan tinggi memenuhi aspek novelty (Kwon, Park, \& Park, 2006; Silver, 1994; Siswono, 2010).

Ada beberapa faktor yang memengaruhi kemampuan siswa dalam menyelesaikan masalah open-ended, yaitu kemampuan berpikir divergen (divergent thinking) dan kemampuan matematis (mathematical abilities). Berpikir divergen merupakan salah satu karakteristik berpikir kreatif (Kwon, Park, \& Park, 2006; Ramzan \& Shaheen, 2011). Siswa yang berkemampuan tinggi mampu berpikir secara luas untuk membuat banyak jawaban benar yang berbeda. Temuan tersebut sesuai dengan definisi divergent thinking yaitu berpikir secara luas yang menghasilkan beragam solusi atau jawaban (Iwata, 2000). Fokus 
dari divergent thinking adalah pada kualitas dan kuantitas dari ide atau respon yang dihasilkan oleh penyelesai masalah dalam proses menyelesaikan masalah. Berpikir divergen merupakan kemampuan yang dibutuhkan untuk dapat menghasilkan beragam respon yang dapat diterima dari permasalahan yang diberikan. Di samping itu, ia mampu menerapkan banyak ide sehingga fleksibel dalam membuat bangun datar yang di antara banyak jawaban terdapat jawaban yang "berbeda". Hal tersebut sesuai dengan pendapat Runco dan Guilford (Sak, 2005) yang menyebutkan bahwa berpikir berbeda didefinisikan sebagai kemunculan dan penerapan dari banyak ide untuk menyelesaikan masalah yang diberikan.

Tingkat kreativitas setiap siswa berbeda (Pehkonen, 1997; Siswono, 2010). Oleh karena itu, tingkat kemampuan berpikir divergen setiap siswa juga berbeda. Tingkat kemampuan berpikir divergen siswa yang berkemampuan tinggi lebih tinggi dari pada siswa yang berkemampuan di bawahnya. Hal tersebut tampak dari hasil pekerjaan tertulis keduanya. Jawaban yang dibuat oleh subjek berkemampuan tinggi lebih beragam bahkan ada diantaranya jawaban yang "berbeda". Subjek yang berkemampuan sedang kurang dapat memunculkan dan menerapkan banyak ide dalam menjawab masalah open-ended. Begitu pula dengan subjek yang berkemampuan rendah, ia tidak mampu memunculkan dan menerapkan banyak ide untuk menghasilkan jawaban yang beragam. Faktor lain yang memengaruhi kemampuan siswa dalam menyelesaikan masalah open-ended adalah kemampuan matematis. Krutetski (2004) mengatakan bahwa kemampuan matematis setiap orang berbeda.

\begin{abstract}
... some persons have inborn characteristics in the structure and functional features of their brains which are extremely favourable to the development of mathematical abilities . . . anyone can become an ordinary mathematician; one must be born an outstandingly talented one.
\end{abstract}

Berdasarkan pendapat Krutetski setiap siswa memiliki struktur dan fitur fungsional otak yang berbeda-beda. Di antaranya ada yang memiliki struktur dan fitur fungsional otak yang sangat menguntungkan untuk mengembangkan kemampuan matematikanya. Peneliti menangkap bahwa ada siswa yang memang memiliki "gift" berupa kemampuan matematis yang baik sehingga ia dapat dengan mudah menyelesaikan masalah matematika. Hal tersebut sejalan dengan teori pemrosesan informasi di mana pada saat dihadapkan dengan suatu masalah maka seseorang akan memanggil informasi yang telah disimpan di long term memory atau memori jangka panjang (Slavin, 2005). Informasi tersebut dapat berupa topik-topik matematika yang telah dipelajari sebelumnya dan dipahami dengan baik sehingga secara otomatis disimpan dalam memori jangka panjang. Kapasitas seseorang menjalankan ingatan dipengaruhi oleh latar belakang pengetahuannya. Semakin seseorang itu mengetahui sesuatu, maka akan semakin mudah dalam mengorganisir dan menyerap informasi yang baru. Sehingga pada saat dihadapkan dengan masalah ia akan menghubungkan informasi yang ada di masalah dengan topik matematika yang telah ia pelajari sebelumnya. Kemampuan tersebut disebut dengan kemampuan koneksi matematis (NTCM, 2000). Secara matematis, siswa mengambil prosedur dalam menyelesaikan masalah matematika yang mereka yakini dapat mengikuti langkahnya termasuk mencoba ide-ide secara sistematis memungkinkan mereka dapat melihat ide yang dapat dipahami dan mana yang tidak.

Siswa yang berkemampuan tinggi memiliki pemahaman yang bagus tentang konsep luas dan bangun datar sehingga pada saat ia dihadapkan dengan masalah yang berkaitan dengan konsep luas dan bangun datar ia memanggil informasi lama dalam hal ini adalah materi luas dan bangun datar yang pernah ia pelajari sebelumnya. Ia mampu menghubungkan antar topik matematika sehingga dapat membuat banyak jawaban berbeda dengan cara yang beragam.

\title{
SIMPULAN
}

Berdasarkan temuan hasil penelitian dan pembahasan dalam penelitian ini maka dapat disimpulkan bahwa siswa yang berkemampuan tinggi mampu berpikir secara luas untuk membuat banyak jawaban benar yang berbeda. Ia mampu menerapkan banyak ide sehingga fleksibel dalam membuat bangun datar yang di antara banyak jawaban terdapat jawaban yang "berbeda". Oleh karena itu siswa yang berkemampuan matematis tinggi dalam mengerjakan soal open-ended memenuhi ketiga aspek, yaitu fluency, flexibility, dan novelty. Subjek yang berkemampuan sedang kurang dapat memunculkan dan menerapkan banyak ide dalam menjawab masalah open-ended. Begitu pula dengan subjek yang berkemampuan rendah, ia tidak mampu memunculkan dan menerapkan banyak ide untuk menghasilkan jawaban yang beragam. Oleh karena itu, baik siswa yang berkemampuan sedang atau rendah tidak dapat membuat jawaban yang "berbeda".

Siswa berkemampuan matematis sedang dalam mengerjakan soal open-ended mampu membuat banyak jawaban benar yang berbeda (fluency) dan mampu membuat jawaban berbeda dengan fleksibel (flexibility) atau hanya memenuhi aspek fluency saja. Siswa yang berkemampuan matematis rendah dalam mengerjakan soal open-ended tidak memenuhi ketiga aspek. Pada sub bab pendahuluan sudah banyak dijelaskan tentang pentingnya penggunaan masalah open-ended dalam pembelajaran matematika di kelas. Akan tetapi, fakta di lapangan yaitu di tempat dilaksanakannya penelitian ini penggunaan soal open-ended dalam pembelajaran matematika dapat dikatakan masih sangat jarang. Siswa belum mendapatkan pengalaman yang cukup dalam menyelesaikan masalah open-ended. Padahal jika siswa sudah terbiasa mengerjakan masalah open-ended kemampuannya dalam menyelesaikan masalah open-ended dapat dieksplorasi lebih dalam lagi. Oleh karena itu, penting bagi peneliti untuk memberikan latihan mengerjakan masalah open-ended dan membahas jawabannya dalam diskusi kelas sebelum penelitian dilaksanakan. 


\section{DAFTAR RUJUKAN}

Becker, J. P., \& Shimada, S. (1997). The Open-Ended Approach: A New Proposal for Teaching Mathematics, National Council of Teachers of Mathematics. Reston, VA: 1906 Association Drive.

Fatah, A., Suryadi, D., \& Sabandar, J. (2016). Open-Ended Approach : An Effort In Cultivating Students' Mathematical Creative Thinking Ability and Self-Esteem In Mathematic. Journal on Mathematics Education, 7(1), 11-20.

Goldberg, F. M., \& McDermott, L. C. (1986). Student Difficulties in Understanding Image Formation by a Plane Mirror. The Physics Teacher, 24(8), 472-481.

Imai, T. (2000). The Relationships between Fluency and Flexibility of Divergent Thinking in Open Ended Mathematics Situation and Overcoming Fixation in Mathematics on Japanese Junior High School Students. In PME Conference, 3-79.

Iwata, K. (2000). What is the Divergent Thinking?: Four Types of Local Divergent Thinking. In PME Conference, 1-203.

Joseph, Y. K. K. (2009). Integrating Open-Ended Problems in the Lower Secondary Mathematics Lessons. In Mathematical Problem Solving: Yearbook 2009, Association of Mathematics Educators, 226-240.

Kwon, O. N., Park, J. S., \& Park, J. H. (2006). Cultivating Divergent Thinking in Mathematics through Open-Ended Approach. Asia Pacific Education Review, 7(1), 51-61.

Nohda, N. (2000). Teaching by Open-Approach Method in Japanese Mathematics Classroom.

NTCM. (2000). Principles and Standards for School Mathematics.

Okabe, H., Hirotani, S., \& Sakata, H. (2000). Learning Guidance for Developing Creative Abilities and Attitude: Applying the Open Approach Method in the Mathematical Learning Process. In PME Conference, 1-179.

Pehkonen, E. (1997). Fostering of Mathematical Creativity. ZDM, 29, 63-67.

Ramzan, S. I., \& Shaheen, P. (2011). Research Papers Divergent Thinking And Creative Ideation. I-Manager's Journal on Educational Psychology, 5(2), 9-14.

Sak, U. (2005). Divergence and Convergence of Mental Forces of Children in Open and Closed Mathematical Problems. International Education Journal, 6(2), 252-260.

Silver, E. A. (1994). On Mathematical Problem Posing. For the Learning of Mathematics, 14(1), 19-28.

Silver, E. A., \& Cai, J. (1996). An Analysis of Arithmetic Problem Posing by Middle School Students. Journal for Research in Mathematics Education, 27(5), 521-539.

Siswono, T. Y. E. (2010). Leveling Students Creative Thinking In Solving. Journal on Mathematics Education, 1(1), 17-40.

Slavin, R. E. (2005). Cooperative Learning Theory, Research and Practice. Bandung: Nusa Media. 